称分子踚文保 (Kobunshi Ronbunshu), Vol. 37, No. 12, pp. 809-814 (Dec., 1980)

\title{
ポリ(アセトキシメチルビニルケトン) の合成とその光分解
}

\author{
伊藤住垡*1・吉田 弘*1
}

(受付 1980 年 2 月 22 日・查終了 1980 年 7 月 20 日)

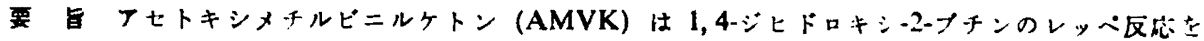

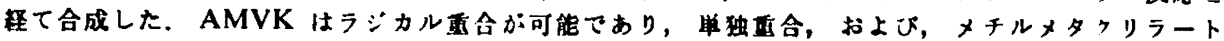
(MMA) またはスチレン (St) この共直合を行った。モノマー反応性比は, $\operatorname{MMA}\left(\mathrm{M}_{1}\right)-\operatorname{AMVK}\left(\mathrm{M}_{2}\right)$ で $r_{1}=0.95, r_{2}=0.77$, そして, St $\left(\mathrm{M}_{1}\right)-\operatorname{AMVK}\left(\mathrm{M}_{2}\right)$ て $r_{1}=0.10, r_{2}=0.36$ が得られた. AMVK-

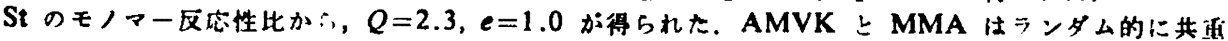

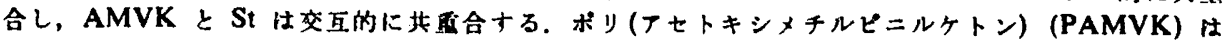

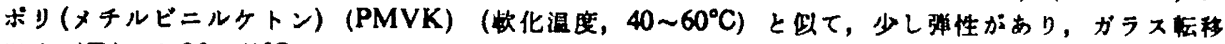
沿度 $\left(T_{\mathrm{g}}\right)$ が $36 \sim 41^{\circ} \mathrm{C}$ であった．ポリマーの光分解性は溶液中， $285 \mathrm{~nm}$ と $312 \mathrm{~nm}$ テ测定した。 ポリマー主镍の切断は gel-permeation chromatography で水め,その量子収浓は, PAMVK で (2.4 2.7) $\times 10^{-2}$, ポリ(ア七トキシメチルピニルケトンーメチルメタクリラート)[P(AMVK-MMA)] テ (1.6 3.3) $\times 10^{-2}$, ボリ(ナセトキシメチルビニルケトンースチレン) [P(AMVK-St)] (3.4〜 5.7) $\times 10^{-2}$ であり, PMVK $\left(\phi_{\mathrm{rs}}=2 \times 10^{-2}\right)$ 上ほぼ同しくくけいの光分解性であった。
\end{abstract}

\section{1 粕言}

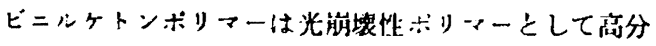
子処理のら天で让日されだか，设近法光分解型の画像 形成材料としても研究されており2), Deep UV 材料と
しても市眅されている゙．こひ注か多くの绕存のケトン

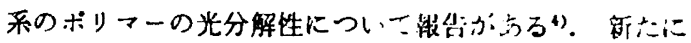
フセトキシメチルビニルケトン (AMVK) を以下の程

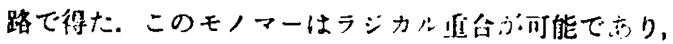

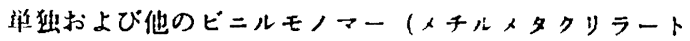

$$
\begin{aligned}
& \mathrm{HOCH}_{2} \mathrm{C} \equiv \mathrm{CCH}_{2} \mathrm{OH} \frac{+\mathrm{H}_{2} \mathrm{O}}{\mathrm{HgSO}_{4}} \rightarrow \mathrm{HOCH}_{2} \mathrm{CCH}_{2} \mathrm{CH}_{2} \mathrm{OH} \frac{\cdot\left(\mathrm{CH}_{3} \mathrm{CO}_{2} \mathrm{O}\right.}{\text { Pyridine }} \\
& \mathrm{CH}_{3} \mathrm{COCH}_{2} \mathrm{COCH}_{2} \mathrm{CH}_{2} \mathrm{OCCCH}_{3} \frac{-\mathrm{CH}_{3} \mathrm{COOH}}{48-49 \mathrm{C} / 1.5 \mathrm{mmHg}} \longrightarrow \mathrm{CH}_{30} \mathrm{COCH}_{20} \mathrm{CH}_{\mathrm{O}} \mathrm{CH}_{2}
\end{aligned}
$$

(MMA)，またはスチレン (St)) と其欣台するのでその

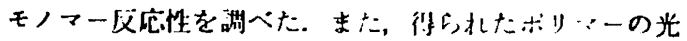
分解性を梌就した。

\section{2 実笂}

\subsection{AMVK の合成}

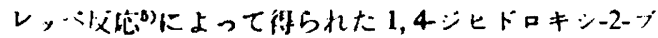

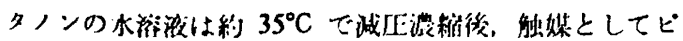

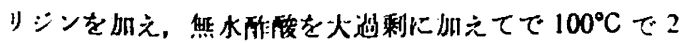

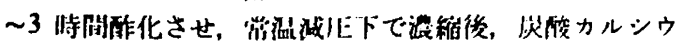

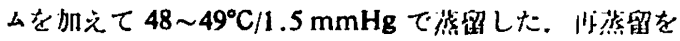

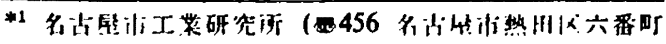
3-24)

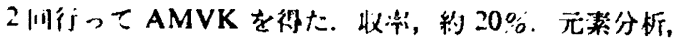

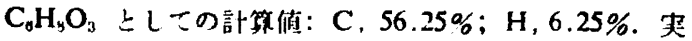

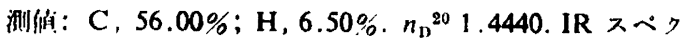

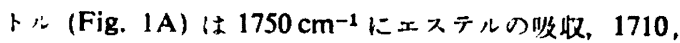
$1695 \mathrm{~cm}^{-1}$ : $\alpha \beta$ 不跑利ヶトンの吸收, $1610 \mathrm{~cm}^{-1}$ Kビ ニル尖の临收を尔した。 また，NMR スベクル（Fig.

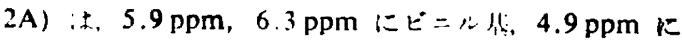

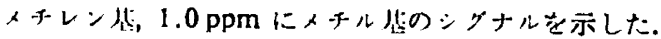

2.2 AMVK の巣独重合および NMA または St と の共重合

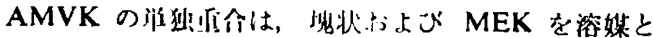

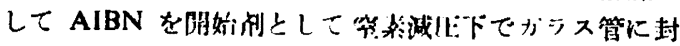

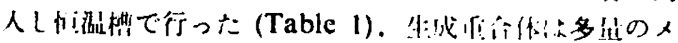




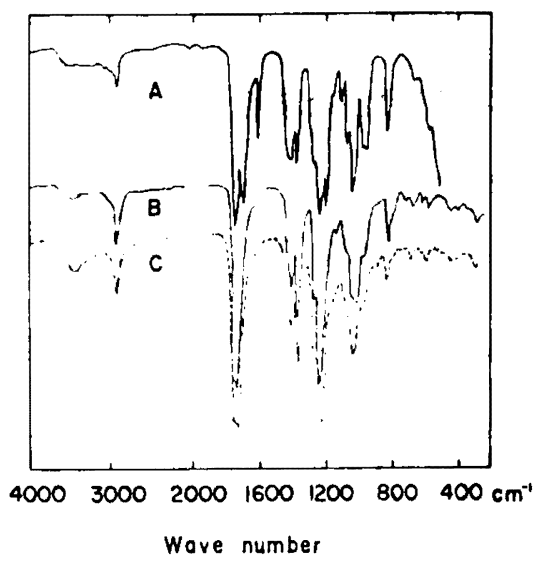

Fig. 1. IR spectra: A, AMVK; B, PAMVK; C, after irradiation* of PAMVK.

* $4 \mathrm{~h}$ by a Toshiba SHL-100 UV from a distance of $10 \mathrm{~cm}$.

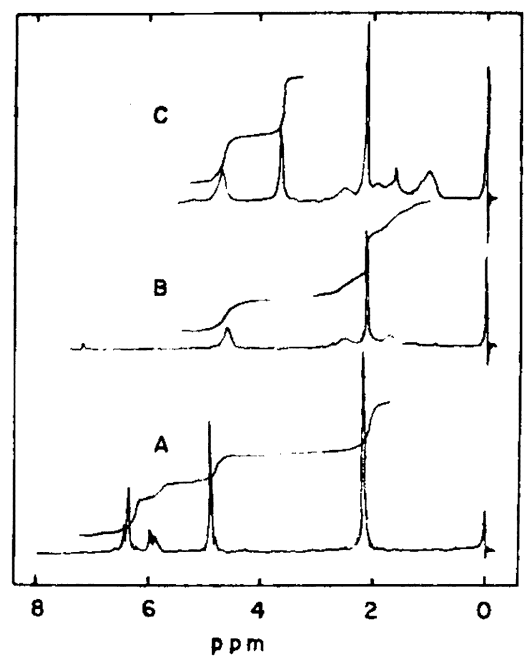

Fig. 2. NMR spectra: A, AMVK; B, PAMVK; C, P(AMVK-MMA).

Table 1. Polymerization of AMVKa)

\begin{tabular}{cccccc}
\hline \hline $\begin{array}{c}\text { Exptl } \\
\text { No. }\end{array}$ & $\begin{array}{c}\text { AMV K } \\
(\mathrm{mol} / l)\end{array}$ & $\begin{array}{c}\text { A I B N } \\
(\mathrm{mol} / l)\end{array}$ & $\begin{array}{c}\text { Time } \\
(\mathrm{h})\end{array}$ & $\begin{array}{c}\text { Conversion } \\
(\%)\end{array}$ & $M_{n}{ }^{\mathrm{b})}$ \\
\hline $1-1$ & 4.2 & $3.0 \times 10^{-2}$ & 1 & 40 & \\
$1-2$ & 1.6 & $1.2 \times 10^{-2}$ & 52 & 74 & $4.8 \times 10^{4}$ \\
$1-3$ & 2.6 & $1.0 \times 10^{-2}$ & 5 & 81 & \\
$1-4$ & 4.9 & $1.9 \times 10^{-2}$ & 6.6 & $\left.87^{\mathrm{c}}\right)$ & $57 \times 10^{4}$ \\
$1-5$ & 4.3 & $\left.1.5 \times 10^{-2 \mathrm{~d}}\right)$ & 4 & 54 & 5 \\
$1-6$ & 8.0 & $1.1 \times 10^{-2}$ & 0.6 & 5 & \\
\hline
\end{tabular}

*) Solvent, methyl ethyl ketone (MEK); temperature, $50^{\circ} \mathrm{C}$.

b) Osmometory. c) Gelation. a) Benzoyl peroxide (BPO).

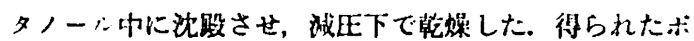
リマーはポリ䣫酸ビニルと同じよらに弾性があり、ア七 トン,テトラヒドロフラン.(THF)， ジオキサンなととに

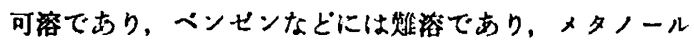
などに不澄である. PAMVK の IR スベクトル (Fig. 1 B) は $1610 \mathrm{~cm}^{-1}$ のビ二ル热が消えて拈り，テのため, 共役のケトン然は $1720 \mathrm{~cm}^{-1}$ にシフトしている。 また， NMR スベクトル (Fig. 2 B) はビニル热が消えて新た に 1.7 と $2.5 \mathrm{ppm}$ にポリマー隹銷のイチン, メチレン 基が現れ心。

MMA またはSt との背近台は MEK を济㩒，テッ゙ ビスインブチロニトリル (AlBN) を開始剂として行っ た (Table 2). 其重合体の紐成は，MMA 其画台体に ついては NMR スペクトル (Fig. 2 C)により AMVK ニニット $4.7 \mathrm{ppm}$ のメチレン基と $\mathrm{MMA}=ニ$ ニの $3.6 \mathrm{ppm}$ のメチル基の秋分低から計笕して求めた。 ま

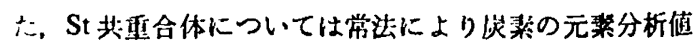
から求めた．重合新を10\% 以下にととめ得た共重合 体組成曲線を Fig. 3 に示寸. Table 2 により FinemanRoss 法に従ってモノアー反応性比を計第した (Fig. 4, Fig. 5).

その結果, $\operatorname{MMA}\left(\mathrm{M}_{1}\right), \operatorname{AMVK}\left(\mathrm{M}_{2}\right)$ の反分性比は, $r_{1}=0.95, r_{2}=0.77$ であり, St $\left(\mathrm{M}_{1}\right), \operatorname{AMVK}\left(\mathrm{M}_{2}\right)$ は, $r_{1}=0.10, r_{2}=0.36$ であった。

AMVK の Alfrey Price の $Q$, e 值は, St の値を $Q=1.0, e=-0.8$ として計算すると $Q=2.3, e=1.0$ であった。

\section{3 ボリマーの光分解}

フィルム状での测定は，ガラス板の上に䄪 $1.5 \mu \mathrm{m} の$ フィルムを作成し, $10 \mathrm{~cm}$ の距崔で超满压水銀奵 (SHL100UV: 來芝(株)裂) の光を照射した．その光分解によ

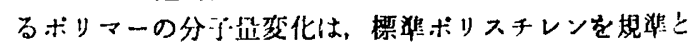


ポリ(ナヒトキシメチルビニルケトン)の合成ともの光静

Table 2. Copolymerization of $\mathrm{AMVK}^{\mathrm{a})}$

\begin{tabular}{|c|c|c|c|c|c|c|c|c|}
\hline $\begin{array}{l}\text { Exptl } \\
\text { No. }\end{array}$ & $\begin{array}{c}\operatorname{AMVK} \\
\left(\mathrm{M}_{1}\right) \\
(\mathrm{mol} / \mathrm{l})\end{array}$ & $\begin{array}{c}\underset{M M A}{M} \\
\left(\mathrm{Mol}_{2}\right)\end{array}$ & $\begin{array}{c}\mathrm{St} \\
\left(\mathrm{M}_{2}\right) \\
(\mathrm{mol} / l)\end{array}$ & $\begin{array}{l}\mathrm{M}_{2} \text { in } \\
\text { monomer } \\
\text { mixture } \\
(\mathrm{mol} \%)\end{array}$ & $\underset{\text { (h) }}{\text { Time }}$ & $\begin{array}{c}\text { Conversion } \\
(9 / 6)\end{array}$ & $\begin{array}{l}\mathrm{M}_{2} \text { in } \\
\text { copolymer } \\
\text { (mol\%) }\end{array}$ & $M_{n}^{b)}$ \\
\hline $2-1$ & 1.6 & 1.6 & t & 50.0 & 2 & 20 & & $24 \times 10^{4}$ \\
\hline $2-2$ & 0.87 & 0.87 & & 50.0 & 52 & 95 & & $10.1 \times 10^{4}$ \\
\hline $2-3$ & 2.18 & 0.93 & & 30.0 & 0.6 & 8.8 & 29.5 & \\
\hline $2-4$ & 1.89 & 1.26 & & 40.0 & 0.6 & 6.8 & 36.7 & \\
\hline $2-5$ & 1.59 & 1.59 & & 49.9 & 0.4 & 3.0 & 45.8 & \\
\hline $2-6$ & 0.97 & 2.26 & & 69.1 & 0.6 & 8.8 & 65.8 & \\
\hline $2-7$ & 0.95 & 2.35 & & 71.2 & 0.4 & 2.9 & 65.2 & \\
\hline $2-8$ & 0.65 & 2.61 & & 80.0 & 0.4 & 2.6 & 75.9 & \\
\hline $3-1$ & 1.60 & & 1.60 & 50.0 & 1.5 & 16 & 40.5 & \\
\hline $3-2$ & 0.86 & & 0.86 & 50.0 & 52 & 82 & 43.8 & $9.4 \times 10^{4}$ \\
\hline $3-?$ & 2.16 & & 0.93 & 30.7 & 0.7 & 9.5 & 36.2 & \\
\hline$\therefore i$ & 1.88 & & 1.25 & 40.0 & 0.7 & 9.6 & 40.5 & \\
\hline $3-5$ & 1.57 & & 1.68 & 51.8 & 0.4 & 2.6 & 45.4 & \\
\hline $3-6$ & 0.96 & & 2.31 & 70.6 & 0.4 & 2.0 & 52.3 & \\
\hline $3-7$ & 0.80 & & 2.41 & 75.1 & 0.4 & 1.9 & 54.0 & \\
\hline
\end{tabular}

s) Solvent. MEK: AIBN. $5.5 \times 10^{-2} \mathrm{~mol} / \mathrm{l}$; temperature, $50^{\circ} \mathrm{C}$. b) Osmometory.

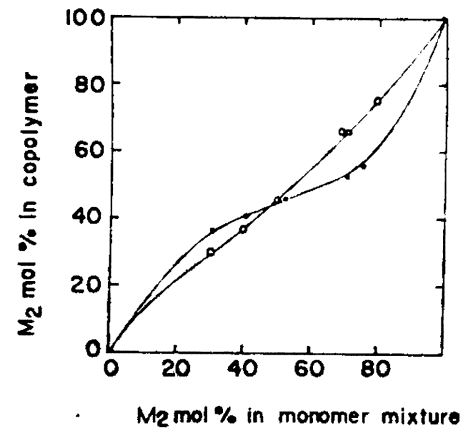

Fig. 3. Composition curve of copolymerization of MMA or St $\left(M_{1}\right)$ with $\operatorname{AMVK}\left(M_{2}\right): 0$. MMA-AMVK system; O, St-AMVK system.

するゲルハーミェーションクロマトリラフ GPC (A-20:

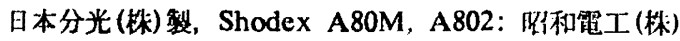
㤠）により测定した。 その結梁を Fig. 6 :皂す。

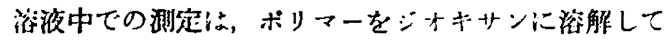
间折格子熙射分光器 (CRM-FA 型: 11本分光 (株)製) 汇 より分光された $312 \mathrm{~nm}\left(4 \times 10^{-8}\right.$ cinstein s $\left.\mathrm{s}^{-1} \mathrm{~cm}^{-2}\right)$ 亡 $285 \mathrm{~nm}\left(2.3 \times 10^{-8}\right.$ einstein $\left.\mathrm{s}^{-1} \mathrm{~cm}^{-2}\right)$ の光を当てて行っ た. ポリーーーの主锁切断の量子収染 $\left(\phi_{\mathrm{cs}}\right)$ は次式上り水 めた。

$$
\phi_{\mathrm{cs}}=\frac{S}{M_{n_{0}} I}
$$

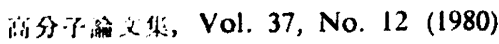

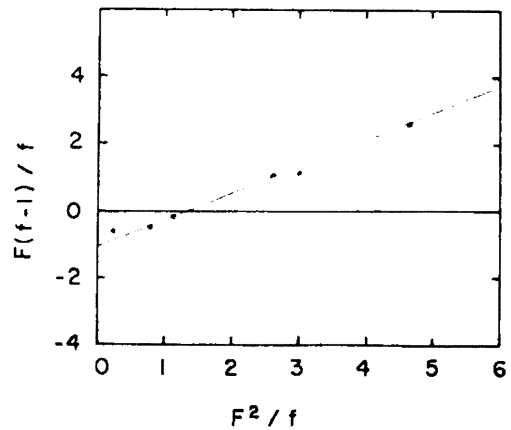

Fig. 4. Fineman-Ross plot of $\operatorname{MMA}\left(\mathrm{M}_{1}\right)$ $\operatorname{AMVK}\left(\mathrm{M}_{2}\right):\left[\mathrm{M}_{1}\right] /\left[\mathrm{M}_{2}\right]=F ; \mathrm{d}\left[\mathrm{M}_{1}\right] / \mathrm{d}\left[\mathrm{M}_{2}\right]=f$.

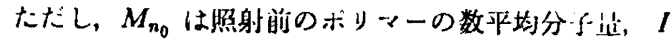
はポリマーに吸収された光理， $S$ はポリマーの主鎖奶断 数 (= $\left.M_{n_{0}} / M_{n_{t}}-1\right)$ である.

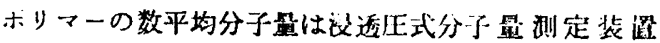
(502 High Speed Membrane Osmometer: Hewlett Packard 社慗)により湘定した。吸収光监は，ポリマ 一浴液 $(1.66 \mathrm{mg} / \mathrm{ml})$ を石英セル $(1 \times 1 \times 4.5 \mathrm{~cm})$ に入 れて室温で照射するとき，その七ル背後に郎いた鉄 (IV) オキサラト化学光量計 ${ }^{()}$により测定して得た. ポリマー

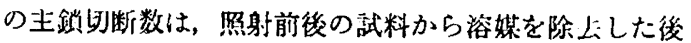
锚评ポリスチレンで較正した GPCで得られた数平均分

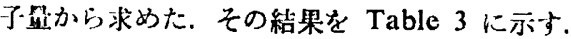




\section{3 考察}

\subsection{ANIK の合成}

1,4ジヒドロキシ-2-プタノンは，水溶波中では妧运に 存在するふ，高温で泿縮するこビニル化を起こして容易 にとドロキシタ基上反応し，分子蝴大をくなる。した

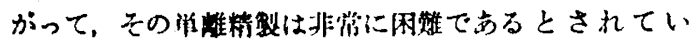
ろ8). 1,4ジヒドロキシー2-ブタ,ンの両末湍をてセチル 化すれば，藂留中に生しるビ二ル基は反応せずにAMVK として留主する。

\subsection{AMVK の等独百合および MMA またはSt と の共姐合}

メチルビニルケトン (MVK) のラジカル画合は、不均 一な再合を起こして不溚证ホリマーが得られることが知

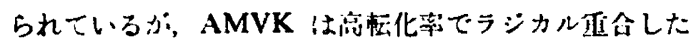

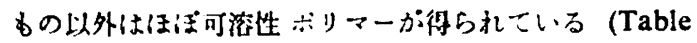
1). ポリ(フセトキシィチルビニルケトン) (PAMVK) は, PMVK (軟化温底, $40^{\circ} \sim 60^{\circ} \mathrm{C}$ ) やポリ醀酸ビ二ル。 (ガラス枟温度 $\left(T_{\mathrm{z}}\right), 30^{\circ} \mathrm{C}$; 軟化温度, $35 \sim 50^{\circ} \mathrm{C}$ ) と

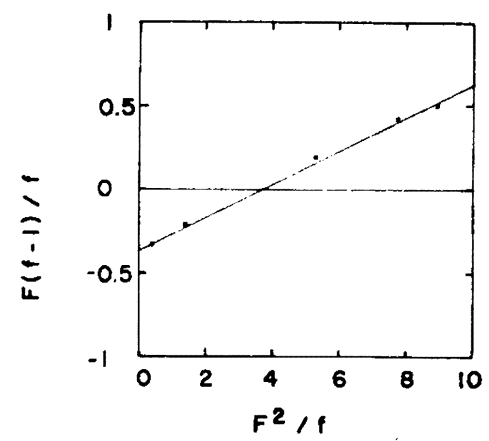

Fig. 5. Fineman-Ross plot of $\mathrm{St}\left(\mathrm{M}_{1}\right)-\mathrm{AMVK}$ $\left(\mathrm{M}_{2}\right):\left[\mathrm{M}_{1}\right] /\left[\mathrm{M}_{2}\right]=F ; \mathrm{d}\left[\mathrm{M}_{1}\right] / \mathrm{d}\left[\mathrm{M}_{2}\right]=f$.
似て, 少し强性があり, その $T_{\mathrm{g}}$ は 36 41 ${ }^{\circ} \mathrm{C}$ (DSC-30 $\mathrm{M}$; (株) 的津製作所製)であった。

MMA との其重合では，そのモノフー反综性此によ 1) AMVK と MMA はランダム的に共聶合することが わかった，MVK-MMA の共血合す闹しようにラング

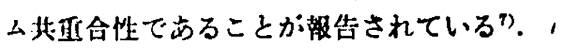

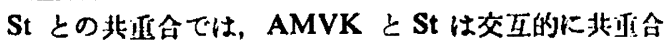
することがわかった. MVK-St'五，エチルビニルケトンー

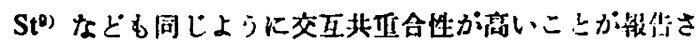
れている。

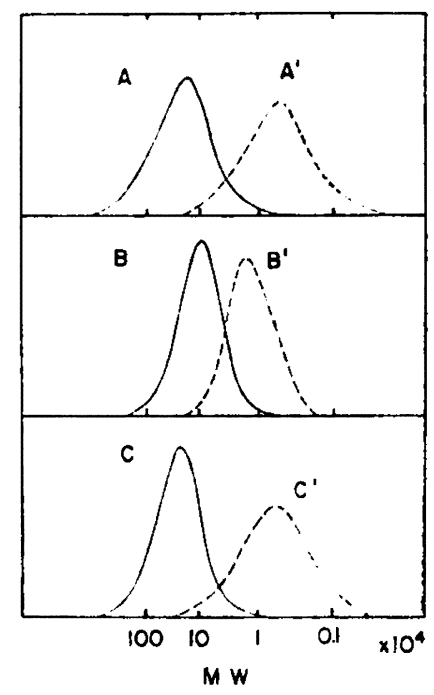

Fig. 6. GPC traces for photolysis of polymers: A, PAMVK; $\mathbf{A}^{\prime}$, after irradiation* of A; B. P(AMVK-MMA); $B^{\prime}$, after irradiation* of $B$; C, $\mathbf{P}\left(\right.$ AMVK-St) ; $\mathbf{C}^{\prime}$, after irradiation ${ }^{*}$ of $\mathrm{C}$.

* $4 \mathrm{~h}$ by a Toshiba SHL-100 UV from a distance of $10 \mathrm{~cm}$.

Table 3. Quantum yield of chain scisson of polymers

\begin{tabular}{|c|c|c|c|c|}
\hline \multirow{2}{*}{$\begin{array}{c}\text { Sample } \\
\text { No. }\end{array}$} & \multirow{2}{*}{$\begin{array}{c}\text { Intensity of absorbed } \\
\text { light }(I) \\
\text { (Einsteins } \mathrm{g}^{-1} \text { ) }\end{array}$} & \multirow{2}{*}{$\begin{array}{l}\text { Number of chain") } \\
\text { scission }(S) \\
\left(\frac{M_{n_{0}}}{M_{n_{t}}}-1\right)\end{array}$} & \multicolumn{2}{|c|}{$\phi_{\mathrm{c}}$} \\
\hline & & & $312 \mathrm{~nm}$ & $285 \mathrm{~nm}$ \\
\hline \multirow[t]{2}{*}{$1-2$} & $2.65 \times 10^{-8}$ & 2.20 & $1.7 \times 10^{-2}$ & \\
\hline & $1.67 \times 10^{-8}$ & 2.64 & & $3.3 \times 10^{-2}$ \\
\hline $1-5$ & $2.43 \times 10^{-8}$ & 22.3 & $1.6 \times 10^{-2}=$ & \\
\hline $2-1$ & $1.56 \times 10^{-8}$ & 9.0 & $2.4 \times 10^{-2}$ & \\
\hline \multirow[t]{2}{*}{$2-2$} & $1.57 \times 10^{-3}$ & 4.7 & $2.7 \times 10^{-2}$ & \\
\hline & $1.60 \times 10^{-3}$ & 4.0 & & $2.4 \times 10^{-}=$ \\
\hline \multirow[t]{2}{*}{$3-2$} & $1: 79 \times 10^{-8}$ & 9.51 & $5.7 \times 10^{-2}$ & \\
\hline & $1.65 \times 10^{-8}$ & 5.31 & & $3.4 \times 10^{-2}$ \\
\hline
\end{tabular}

2) Gel-permeation chromatography (GPC) was calibrated by use of slandard polystyrene (PSt) sample. 


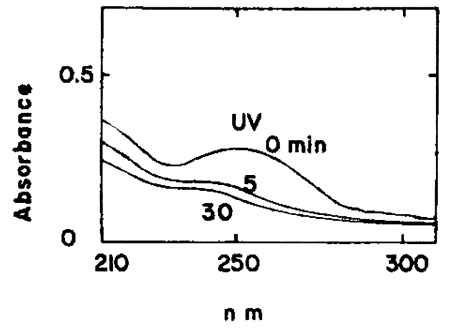

Fig. 7. Change of UV spectrum of PAMVK film on the photoirradiation. Photoirradiation was made by use of Toshiba SHL-100 UV from a distance of $10 \mathrm{~cm}$.

St 上の其亚命から得た $Q, e$ 值は， $Q=2.3, e=1.0$

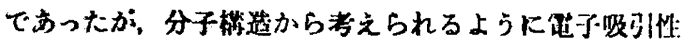
のカルボニル基が二つるあるため正雪価が高く、しかも 背暗効果が芯いことがかかる。

\section{3 光分解性}

フィルム状での AMVK 采六リマーの光分解京，30 分間の光照射で分子照仿 PAMVK で約 1/44，ポり( セトキシメチルビニルケトンーメチルイタクリラート)[P (AMVK-MMA)] で約 1/10，ポり(アセトキシィチルビ ニルケトンースチレン) [P(AMVK-St)] で約 1/62 にな

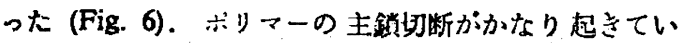
るこ上を示している.

それか之，その主銷切断の量子収率（ジオナサン小） を求めた (Table 3). ボリマー主鎖切断数 (S) は, 柴 整ボリスチレンで較正した GPC による数平均分子早 (GPC 法) からら求めたので実駼俱差が含まれる。しか L, $S=M_{n_{0}} / M_{n_{t}}-1 \approx M_{n_{0}}{ }^{*} / M_{n_{t}}{ }^{*}-1$ (* GPC 法) であ

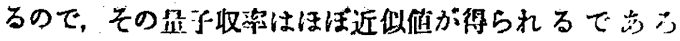
5. Guillet 5を P(MVK-MMA) の $\phi_{\mathrm{cs}}$ を GPC 沙

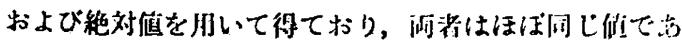
った'10).

PAMVKは $285 \mathrm{~nm}$ 付近にケトンの $n-\pi^{*}$ 枟位によ

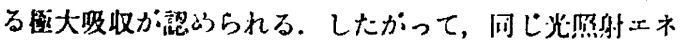
ルギーで比べれば $312 \mathrm{~nm}$ 上り $285 \mathrm{~nm}$ での光分解の 効赑は商いであろ5. PAMVK の $\phi_{\mathrm{cs}}$ は, PMVKの $\phi_{\mathrm{cn}}$ 0.02 0.02511) と注汪同しで苟ることがわかった。

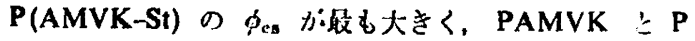

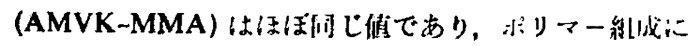
占めるケトンの绪合上 $\phi_{\mathrm{cs}}$ とは此例していない。これら の理山は, Kiwi ${ }^{12)}$ らのフェニルビニルケトン (PVK) の St コポリーーおよび MMA ュポリマー, VAcコ卡 リマーのレーザー光分解による三画项序命の测起につい ての能告により论のように考えられる。すなわり， St コ ポリマー(56.2\% AMVK)が没も光分解しやすいのは,

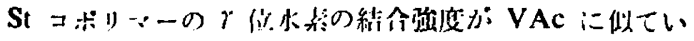

うAMVKのホモポリマーより小さいため水策引汶反応 を起こしやすく(Norrish II 型反伈沈ど)，したが， て, 三重項寿命す短いであらうと考えられる。しかし， MMA コボリマーは，r位水䋈の数がホモボリマー上り も少ないので反応性す小さいはずであるが, MMA こポ リマー (約 50\% AMVK) とホそポリマーは, 炏分解 性が注添间しである。したがって，この例のよらにコボ リマー中の AMVK 組成が 1/2ぐらいまで法， 7 位水

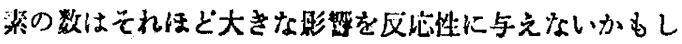
れない。例兰ば, Lukáć19) らによって, PVKの MMA コポリマーの $\phi_{\text {c }}$ は, 29\% PVKがホモボリマーの 12 で㟧ることが解告されている.

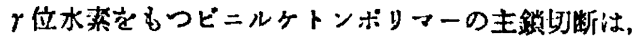

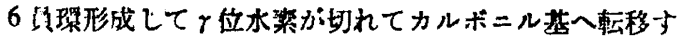
る Norrish II 型機權で進む. PAMVKを光照身け一

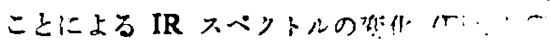

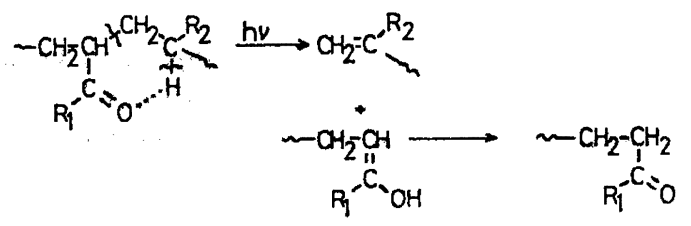

$\mathrm{cm}^{-1}$ の小酸㘳の增加と $1750,1720 \mathrm{~cm}^{-1}$ のカルホニニル 北のわずかな娍少が吠められる. 照射によるUV スベク トルの梦化 (Fig. 7) も全体の吸収が減っており，IRの

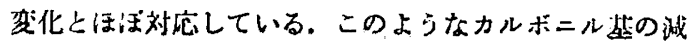

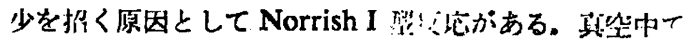<smiles>[R]C(=O)C(CC)CCCCCCCCCCCCCC=O</smiles>

のPAMVK の光分解はーススヘクトルによれば、分解

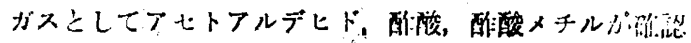
されている. また，IR スベクトルによれば空剠と伍

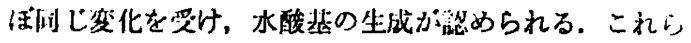
のことより，PAMVK の炎分解は，Norrish $\mathrm{I}$ 型, Norrish II 型反応と同時にエステル装の分解も朴三てい る。した分って，水酸基が生成するいは，エステル莣の 分解に占って非したもの上思れれるか，その他，Norrish

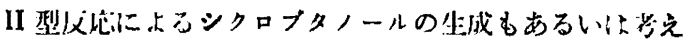
られる.

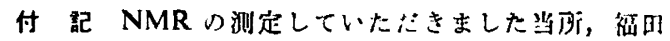

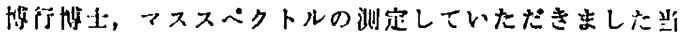

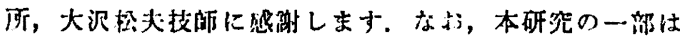

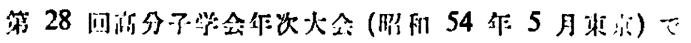
発炏脤。 


\section{文䓟}

1) 例えば, J.W. ヘンリー(イーストマン・コダッ ク)：日特公昭 42-18812 (1967).

2) M. Tsuda, T. Nakamura, S. Oikawa, H. Nagata, A. Yokota, H. Nakane, T. Tsumori, Y. Nakane, and T. Mifune, Photogr. Sci. Eng., 23(5), 290 (1979).

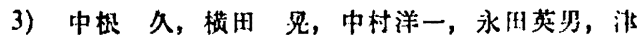
田滕，Decp UVレジスト-ODUR シリーズ, 策 2 回フォトポリマー、コンファレンス撛演要

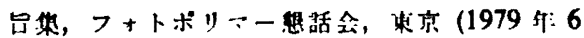
月), p. 71 .

4) 付えば, G.H. Hartley, and J.E. Guillet, Macromolecules, 1(2), 165 (1968).

5) J.W. Copenhaver and M.H. Bigelow, "Acetylene and Carbon Monoxide Chemistry", Reihold, New York, N.Y. (1949), p. 138.

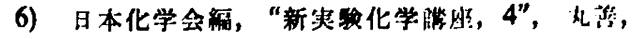
束京 (1976), p. 241.

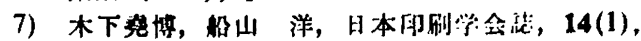
1 (1973).

8) F.M. Lewis and C. Walling, J. Am. Chem. Soc., 70, 1527 (1948).

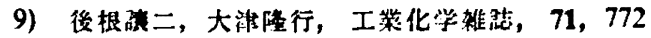
(1968).

10) Y. Amerik and J.E. Guillet, Macromolecules, 4(4), 375 (1971).

11) B. Ranby and J.F. Rabek, "Photodegradation, Photo-oxidation and Photostabilization of Polymers", John Wily \& Sons, New York, N.Y. (1975), p. 84.

12) J. Kiwi and W. Schnabel, Macromolecules, $8(4), 430$ (1975).

13) I. Lukáč, I. Zavara, P. Hrdlovic, and Z. Manasek, Chem. Zvesti., 26, 404 (1972).

\section{Preparation of Poly(acetoxymethyl vinyl ketone)s and their Photolysis}

Nobuyoshi Iro*1 and Hiroshi Yoshida*1

*1 Nagoya Municipal Industrial Research Institute (3-24 Rokuban-cho, Atsuta-ku, Nagoya, 456 Japan)

Acetoxymethyl vinyl ketone (AMVK), prepared through the Reppe reaction of 1,4-dihydroxy-2butyne, was homopolymerized and copolymerized with methyl methacrylate (MMA) or styrene (St) by azobisisobutyronitrile. The monomer reactivity ratio was evaluated as $r_{1}=0.95$ and $r_{2}=0.77$ in copolymerization of $\operatorname{MMA}\left(\mathrm{M}_{1}\right)-\operatorname{AMVK}\left(\mathrm{M}_{2}\right)$, and as $r_{1}=0.10$ and $r_{2}=0.36$ in copolymerization of St $\left(\mathrm{M}_{1}\right)$-AMVK $\left(\mathrm{M}_{2}\right)$. As calculated from the monomer reactivity ratio of AMVK-St, $Q=2.3$ and $e=1.0$. AMVK and MMA copolymerize randomly, while AMVK and St slightly more alternately. The poly(acethoxymethyl vinyl ketone) (PAMVK) was a semielastic mass having the glass-transition temperature $\left(T_{8}\right)$ of $36-41^{\circ} \mathrm{C}$, which is close to the softening temperature of poly (methyl vinyl ketone) (PMVK) $\left(40-60^{\circ} \mathrm{C}\right)$. The quantum yields of chain scission $\left(\phi_{\mathrm{cs}}\right)$ of photolysis at 285 or $312 \mathrm{~nm}$ in solution, determined by gel-permeation chromatography, were $(1.6-3.3) \times 10^{-2},(2.3-2.7) \times 10^{-2}$, and (3.4-5.7) $\times 10^{-2}$, respectively, for PAMVK, poly (acetoxymethyl vinyl ketone-methyl methacrylate), and poly (acetoxymethyl vinyl ketone-styrene), which were of the same order with that for PMVK $\left(2 \times 10^{-2}\right)$.

KEY WORDS Acetoxymethyl Vinyl Ketone/Radical Polımerization / Monomer Reactivity Ratio / Photolysis / Quantum Yield / Chain Scission /

(Received February 22, 1980: Accepted July 20, 1980)

[Kohunshi Ronbunshu, 37(12), 809-814 (1980)] 